\title{
Influence of Precipitation and Sugarcane Straw in AMINOCYCLOPYRACHLOR AND INDAZIFLAM CONTROL EFFICIENCY ${ }^{1}$
}

\author{
Influência da Precipitação e da Palha da Cana-de-Açúcar na Eficiência de Controle do \\ Aminocyclopyrachlor e Indaziflam
}

\author{
GUERRA, N. ${ }^{2}$, OLIVEIRA JR., R. S. ${ }^{3}$, CONSTANTIN. J. ${ }^{3}$, OLIVEIRA NETO, A.M. ${ }^{4}$, PUTON, G. ${ }^{3}$, and \\ GARRIDO, T.H.P. ${ }^{5}$
}

\begin{abstract}
The raw sugarcane harvesting system has changed the dynamics of weed tillage for this crop, changing the predominant weed species and providing a barrier between the herbicide and the soil. Thus, this study has aimed to assess the influence of precipitation and sugarcane straw in the aminocyclopyrachlor and indaziflam herbicides control efficiency for the species Ipomoea triloba and Euphorbia heterophylla. There were two trials, one for aminocyclopyrachlor and one for the indaziflam, both in the greenhouse at the campus of Faculdade Integrado in the Brazilian city of Campo Mourão, PR. Each experiment consisted of eight treatments with four replications. The treatments consisted of the combination of the presence of straw $\left(10 \mathrm{t} \mathrm{ha}^{-1}\right)$, capillary irrigation and rainfall simulation $(20 \mathrm{~mm})$. Assessments of control percentage of I. triloba and E. heterophylla were carried out, as well as the number of plants per pot. The aminocyclopyrachlor and indaziflam herbicides applied directly to the soil were efficient in controlling these species. The $20 \mathrm{~mm}$ rainfall simulation or daily irrigation on the straw are indispensable to promote the removal of aminocyclopyrachlor and indaziflam from the straw and provide satisfactory control of I. triloba and E. heterophylla.
\end{abstract}

Keywords: mulching, Euphorbia heterophylla, Ipomoea triloba, rainfall.

\begin{abstract}
RESUMO - O sistema de colheita da cana crua modificou a dinâmica do manejo de plantas daninhas para essa cultura, alterando as espécies infestantes predominantes e proporcionando uma barreira entre o herbicida e o solo. Com isso, o presente trabalho teve por objetivo avaliar a influência da precipitação e da palhada de cana-de-açúcar na eficiência de controle dos herbicidas aminocyclopyrachlor e indaziflam para as espécies Ipomoea triloba e Euphorbia heterophylla. Foram realizados dois ensaios, um para o aminocyclopyrachlor e outro para o indaziflam, ambos em casa de vegetação no campus da Faculdade Integrado de Campo Mourão-PR. Cada experimento foi composto por oito tratamentos com quatro repetições. Os tratamentos consistiram na combinação entre a presença de palha (10 tha $\left.\mathrm{A}^{-1}\right)$, a irrigação por capilaridade e a simulação de precipitação $(20 \mathrm{~mm}$ ). Foram realizadas avaliações de porcentagem de controle de I. triloba e E. heterophylla além de número de plantas por vaso. Os herbicidas aminocyclopyrachlor e indaziflam aplicados diretamente ao solo foram eficientes no controle dessas espécies. A simulação de precipitação de $20 \mathrm{~mm}$ ou a irrigação diária sobre a palha é indispensável para promover a retirada do aminocyclopyrachlor e indaziflam da palha e proporcionar controle satisfatório de I. triloba $e$ E. heterophylla.
\end{abstract}

Palavras-chave: cobertura morta, Euphorbia heterophylla, Ipomoea triloba, pluviosidade.

Recebido para publicação em 19.3.2015 e aprovado em 12.5.2015.

2 Universidade Federal de Santa Catarina, Curitibanos, SC, Brasil, <naiaraguerra.ng@gmail.com>; ${ }^{3}$ Universidade Estadual de Maringá, Maringá, PR, Brasil; ${ }^{4}$ Empresa de Pesquisa Agropecuária e Extensão Rural de Santa Catarina, Itajaí-SC, Brasil; ${ }^{5}$ Faculdade Integrado de Campo Mourão, Campo Mourão, PR, Brasil. 


\section{INTRODUCTION}

Sugarcane crop has been playing an important role in the Brazilian economy. The big production achieved in recent years and the continued increase in yield have put Brazil as the world's leading in sugarcane's energy agribusiness. According to the União dos Produtores de Bioenergia - UDOP (Union of Bioenergy Producers) (2015), the forecast for the Brazilian yield for the 2014/15 crop is $34,405,921$ tons.

The crop production system of sugarcane has undergone several modifications over the years. The mechanized harvest without previous straw burning is one of the modifications of this production system. The absence of burning ends up leaving a large layer of straw on the soil, which can exceed $20 \mathrm{t} \mathrm{ha}^{-1}$. This harvesting technique has created a new sugarcane production system, popularly known as raw sugarcane (Ferreira et al., 2010). This vegetable waste deposited on the soil changes in a way its microclimate, changing the brightness, temperature and humidity, key elements in the control of dormancy and germination of weed seeds (Correia \& Rezende, 2002; Christofoletti et al., 2009). Among the species that tend to remain as weeds in the raw sugarcane system are Ipomoea triloba (known by several common names, including littlebell and Aiea morning glory) and Euphorbia heterophylla (known under the common names of (Mexican) Fireplant, Painted Euphorbia, Japanese Poinsettia, Desert Poinsettia, Wild Poinsettia, Fire on the Mountain, Paintedleaf, Painted Spurge, Milkweed, and Kaliko Plant) (Martins et al., 1999; Monquero et al., 2009).

In addition to interfering with the weed community, the presence of straw hinders the performance of herbicides, since the main components of the dynamic of herbicides on the straw in areas where there is maintenance of crop residue on the soil surface are the transposition of the product through it and the dynamics of wetting and washing the straw by rainwater (Maciel \& Velini, 2005). The straw intercepts the herbicide, making it vulnerable to volatilization and/or photolysis, until being leached into the soil (Locke \& Bryson, 1997). Lamoreaux et al. (1993) have noted that the transport of the herbicide from the straw into the soil is dependent upon the straw ability to cover the soil and retain these herbicides, the physicochemical characteristics of the herbicide, as well as the period in which the area remains without rain after application.

The aminocyclopyrachlor and indaziflam herbicides are under development in Brazil for the crop of sugarcane (Guerra et al., 2013). Since they are new molecules, there is virtually no literature on the behavior of these herbicides in the raw sugarcane harvesting system. Thus, this study aimed to assess the influence of precipitation and sugarcane straw on the control efficiency of herbicides aminocyclopyrachlor and indaziflam for the species I. triloba and E. heterophylla.

\section{MATERIALS AND METHODS}

Two experiment tests were conducted in a greenhouse at Campus Experimental of Faculdade Integrado of the Brazilian city of Campo Mourão, PR, located on highway rodovia BR 158, km 207, Jardim Batel, Campo Mourão, PR (latitude 23'99'04" south, longitude $52^{\circ} 36^{\prime} 37^{\prime \prime}$ west and average altitude $508 \mathrm{~m}$ ). The soil used as a substrate for both tests was classified as dystrophic red latosol of very clayey texture (Embrapa, 2013), comprising $76 \%$ of clay, $13 \%$ of sand and $11 \%$ of silt, with $\mathrm{pH}\left(\mathrm{H}_{2} \mathrm{O}\right) 5.99$ and $2.3 \%$ of organic matter.

The first test was carried out with herbicide aminocyclopyrachlor between August and October 2013, and the second one with indaziflam during the months of March and May 2014.

The experimental design in both trials was completely randomized, with eight treatments and four replications, totaling 64 experimental units for each experiment. The units were represented by polyethylene pots with a capacity of $3 \mathrm{~kg}$ of substrate. The treatments consisted of the combination of the absence or presence of straw and different forms of precipitation or maintenance irrigation, and two controls without the herbicide. Details of the treatments are presented in the tables with the test results (Tables 1, 2, 3 and 4).

Both experiments were conducted following the sequence: filling the pots with 
the substrate, seeding the weeds, covering with straw (depending on treatment), herbicide application and rainfall simulation (depending on treatment).

After filling the pots, the seeding of 15 seeds of weeds Ipomoea triloba (known by several common names, including littlebell and Aiea morning glory) and Euphorbia heterophylla (known under the common names of (Mexican) Fireplant, Painted Euphorbia, Japanese Poinsettia, Desert Poinsettia, Wild Poinsettia, Fire on the Mountain, Paintedleaf, Painted Spurge, Milkweed, and Kaliko Plant) per pot took place.

Soon after sowing the weeds, $20 \mathrm{~g}$ sugarcane straw were added per pot, in order to simulate a coverage of $10 \mathrm{t} \mathrm{ha}^{-1}$ of straw.

The doses of aminocyclopyrachlor and indaziflam were 90 and $100 \mathrm{~g} \mathrm{ha}^{-1}$, respectively. These doses were based on information provided by the companies with the molecules. In both applications, a sprayer in constant pressure was used, pressurized at $\mathrm{CO}_{2}$ and fitted with a bar containing four spray nozzles in a flat fan jet type AVISO 110.02, spaced $50 \mathrm{~cm}$, under pressure of $206.8 \mathrm{kPa}$, promoting a spray volume of $200 \mathrm{~L} \mathrm{ha}^{-1}$. The experiment with the aminocyclopyrachlor was applied on August 19, 2013. At the time of application, environmental conditions were temperature of $26.7^{\circ} \mathrm{C}$, relative humidity of $49.8 \%$ and winds of $3.0 \mathrm{~km} \mathrm{~h}^{-1}$; the soil was moist. The second experiment was applied on March 14, 2014. At the time of application, environmental conditions were temperature of $30{ }^{\circ} \mathrm{C}$, relative humidity of $62.1 \%$ and winds of $0.2 \mathrm{~km} \mathrm{~h}^{-1}$; the soil was moist.

After application of the herbicide, the pots of treatments 4 and 5 received rain simulation equivalent to $20 \mathrm{~mm}$ of precipitation. The precipitation simulation was done with the aid of a dosing cup with a volume of $400 \mathrm{~mL}$; this volume was placed in a watering can and the pot irrigation took place.

The irrigation to maintain the humidity of the pots was performed with a low flow hose coupled to a drip watering device, two days after herbicide application, and was kept at intervals of a day, except for treatments 5 and 7 , wherein irrigation was carried out by capillarity by means of plates under the pots, supplementing them as needed.

Assessments were done to control Ipomoea triloba and Euphorbia heterophylla at $7,14,21,28$ and 35 days after application (DAA) for the experiment with aminocyclopyrachlor, and at 7, 14, 21 and 28 DAA for the experiment with Indaziflam. As a control assessment criterion, the percentage visual scale proposed by the SBCPD (Sociedade Brasileira da Ciência das Plantas Daninhas; Brazilian Society of Weed Science) (1995) was used, with $0 \%$ representing no control and $100 \%$ representing plant death. Along with the latest control assessment at 35 or 28 DAA for aminocyclopyrachlor and indaziflam, respectively, the number of plants per pot was counted.

The data were submitted to analysis of variance by $\mathrm{F}$-test and the means were compared by Scott-Knott test ( $p<0.05)$.

\section{RESULTS AND DISCUSSION}

The presence of straw equivalent to $10 \mathrm{t} \mathrm{ha}^{-1}$ without the application of aminocyclopyrachlor or indaziflam (T2) was not sufficient to suppress germination and emergence of Ipomoea triloba and Euphorbia heterophylla (Tables 1, 2, 3 and 4). Martins et al. (1999) have found that non even $15 \mathrm{t} \mathrm{ha}^{-1}$ of sugarcane straw are sufficient to inhibit the germination and emergence of $E$. heterophylla. For I. triloba, Monquero et al. (2009) have noted that $10 \mathrm{t} \mathrm{ha}^{-1}$ of straw does not interfere with emergence, but larger amounts of straw (15 and $20 \mathrm{t} \mathrm{ha}^{-1}$ ) reduce the infestation of this species.

\section{Aminocyclopyrachlor}

The means of control and amount percentages of plants for the species $I$. triloba are presented in Table 1. At 14 DAA, the treatments that received an application of aminocyclopyrachlor directly into the soil (T3 and T8) were the only ones to provide satisfactory control (> 80.0\%) of Ipomoea triloba. The same trend can be observed in the assessments performed at 21 and 28 DAA.

In the final assessment, the treatments where the application was done on the soil 
Table 1 - Control percentage at 14, 21, 28 and 35 days after application (DAA) and number of I. triloba plants at 35 DAA of the treatments with aminocyclopyrachlor. Campo Mourão, PR, 2013

\begin{tabular}{|c|c|c|c|c|c|c|c|c|}
\hline \multirow{2}{*}{ Treatment } & \multirow{2}{*}{ Herbicide } & \multirow{2}{*}{$\begin{array}{l}\text { Sugarcane } \\
\text { straw }\end{array}$} & \multirow{2}{*}{$\begin{array}{c}\text { Simulated } \\
\text { rainfall } \\
(\mathrm{mm})\end{array}$} & \multicolumn{4}{|c|}{ Control (\%) } & \multirow{2}{*}{$\begin{array}{c}\begin{array}{c}\text { Number of } \\
\text { plants }\end{array} \\
35 \text { DAA } \\
\end{array}$} \\
\hline & & & & 14 DAA & $21 \mathrm{DAA}$ & $28 \mathrm{DAA}$ & 35 DAA & \\
\hline 1 & Without & Without & Without & $0.0 \mathrm{c}$ & $0.0 \mathrm{c}$ & $0.0 \mathrm{~d}$ & $0.0 \mathrm{e}$ & $3.5 \mathrm{a}$ \\
\hline 2 & Without & With & Without & $0.0 \mathrm{c}$ & $0.0 \mathrm{c}$ & $0.0 \mathrm{~d}$ & $0.0 \mathrm{e}$ & $3.0 \mathrm{a}$ \\
\hline 3 & On the soil & Without & Without & $80.0 \mathrm{a}$ & $72.5 \mathrm{~b}$ & $82.0 \mathrm{~b}$ & $96.2 \mathrm{a}$ & $0.5 \mathrm{~b}$ \\
\hline 4 & On the straw & With & 20 & $18.7 \mathrm{c}$ & $20.0 \mathrm{c}$ & $41.2 \mathrm{c}$ & $78.2 \mathrm{~b}$ & $2.5 \mathrm{a}$ \\
\hline$* 5$ & On the straw & With & 20 & $48.7 \mathrm{~b}$ & $37.5 \mathrm{c}$ & $68.7 \mathrm{~b}$ & $87.0 \mathrm{a}$ & $1.7 \mathrm{a}$ \\
\hline 6 & On the straw & With & Without & $10.0 \mathrm{c}$ & $11.2 \mathrm{c}$ & $28.7 \mathrm{c}$ & $60.0 \mathrm{c}$ & $3.7 \mathrm{a}$ \\
\hline$* 7$ & On the straw & With & Without & $18.7 \mathrm{c}$ & $6.7 \mathrm{c}$ & $16.2 \mathrm{~d}$ & $33.7 \mathrm{~d}$ & $2.5 \mathrm{a}$ \\
\hline 8 & Under the straw & With & Without & $99.2 \mathrm{a}$ & $100.0 \mathrm{a}$ & $100.0 \mathrm{a}$ & $100.0 \mathrm{a}$ & $0.0 \mathrm{~b}$ \\
\hline $\mathrm{CV}(\%)$ & & - & & 46.72 & 59.39 & 34.04 & 16.56 & 48.93 \\
\hline
\end{tabular}

Means followed by the same letter in each column do not differ by the Scott-Knott test $(\mathrm{p}<0.05) .{ }^{*}$ Treatments irrigated by capillarity.

without the presence of straw (T3), with application also on the soil and subsequent addition of straw (T8), with application on the straw and rainfall simulation (T4) and the one which received the application on the straw, with the presence of rainfall and irrigated by capillarity (T5) provided the best means, significantly differing from the other treatments, and promoted the highest levels of control of $I$. triloba. This result suggests that the amount of aminocyclopyrachlor loosened from the straw after the $20 \mathrm{~mm}$ rainfall simulation is sufficient to provide high levels of control for I. triloba. When there is no rainfall after herbicide application, this species control is impaired. Studies by Prado et al. (2010) have shown that a $20 \mathrm{~mm}$ rainfall simulation after application of herbicides diuron, tebuthiuron and metribuzin is sufficient to percolate these herbicides of a straw layer of $10 \mathrm{t}$ per hectare and provide a satisfactory control of $I$. triloba.

The plants number count at 35 DAA confirms the control results (Table 1). The lower means of plant number of $I$. triloba were observed in the treatment with application only on the soil (T3) and on the one which was applied on the soil and straw was added on this one (T8).

With these results, it is observed that the application of aminocyclopyrachlor on the soil presents gains over that performed on the straws, corroborating the data obtained by Carbonari (2007) using herbicide amicarbazone and the data obtained by Cavenaghi et al. (2007), who found that the presence of precipitation is very important for the leaching of amicarbazone applied on sugarcane straw for the soil. This makes clear that rain is an important factor for the percolation of this herbicide, causing the product to reach the soil and reaching the seeds when it is not applied directly. These results corroborate those found by Carbonari et al. (2008), for the species Ipomoea spp., which reinforce that when the herbicide is applied directly on the soil with or without mulching, the results are satisfactory. As for application performed on the straw, a $20 \mathrm{~mm}$ precipitation occurrence is necessary to obtain the same levels of control.

Table 2 shows the control and amount percentages of plants of the species E. heterophylla. The rainfall simulation after application of aminocyclopyrachlor on the straw promoted an excellent control of the E. heterophylla. The treatments with herbicide application done directly into the soil (T3 and T8) promote development inhibition of this species. In applications performed on the layer of straw, rain was essential because it made possible to transport the herbicide from the straw to the soil surface, coinciding with the results by Carbonari et al. (2008).

Of the treatments that received application of aminocyclopyrachlor, the one 
Table 2 - Control percentage at 14, 21, 28 and 35 days after application (DAA) and number of E. heterophylla plants at 35 DAA of the treatments with aminocyclopyrachlor. Campo Mourão, PR, 2013

\begin{tabular}{|c|c|c|c|c|c|c|c|c|}
\hline \multirow{2}{*}{ Treatment } & \multirow{2}{*}{ Herbicide } & \multirow{2}{*}{$\begin{array}{l}\text { Sugarcane } \\
\text { straw }\end{array}$} & \multirow{2}{*}{$\begin{array}{l}\text { Simulated } \\
\text { rainfall } \\
(\mathrm{mm})\end{array}$} & \multicolumn{4}{|c|}{ Control (\%) } & \multirow{2}{*}{$\begin{array}{c}\begin{array}{c}\text { Number of } \\
\text { plants }\end{array} \\
35 \text { DAA }\end{array}$} \\
\hline & & & & $14 \mathrm{DAA}$ & 35 DAA & 28 DAA & 35 DAA & \\
\hline 1 & Without & Without & Without & $0.0 \mathrm{~b}$ & $0.0 \mathrm{~b}$ & $0.0 \mathrm{c}$ & $0.0 \mathrm{c}$ & $2.5 \mathrm{a}$ \\
\hline 2 & Without & With & Without & $25.0 \mathrm{~b}$ & $0.0 \mathrm{~b}$ & $0.0 \mathrm{c}$ & $0.0 \mathrm{c}$ & $3.7 \mathrm{a}$ \\
\hline 3 & On the soil & Without & Without & $99.2 \mathrm{a}$ & $99.2 \mathrm{a}$ & $99.5 \mathrm{a}$ & $99.5 \mathrm{a}$ & $0.2 \mathrm{~b}$ \\
\hline 4 & On the straw & With & 20 & $43.7 \mathrm{~b}$ & $65.0 \mathrm{a}$ & $88.2 \mathrm{a}$ & $99.5 \mathrm{a}$ & $0.5 \mathrm{~b}$ \\
\hline$* 5$ & On the straw & With & 20 & $56.2 \mathrm{~b}$ & $56.2 \mathrm{a}$ & $81.2 \mathrm{~b}$ & $95.7 \mathrm{a}$ & $0.5 \mathrm{~b}$ \\
\hline 6 & On the straw & With & Without & $57.5 \mathrm{~b}$ & $69.2 \mathrm{a}$ & $93.2 \mathrm{a}$ & $98.7 \mathrm{a}$ & $0.2 \mathrm{~b}$ \\
\hline$* 7$ & On the straw & With & Without & $20.0 \mathrm{~b}$ & $36.2 \mathrm{~b}$ & $72.5 \mathrm{~b}$ & $50.0 \mathrm{~b}$ & $1.5 \mathrm{~b}$ \\
\hline 8 & Under the straw & With & Without & $100.0 \mathrm{a}$ & $100.0 \mathrm{a}$ & $100.0 \mathrm{a}$ & $100.0 \mathrm{a}$ & $0.0 \mathrm{~b}$ \\
\hline CV (\%) & & - & & 67.67 & 55.38 & 16.92 & 18.16 & 86.94 \\
\hline
\end{tabular}

Means followed by the same letter in each column do not differ by the Scott-Knott test $(\mathrm{p}<0.05) .{ }^{*}$ Treatments irrigated by capillarity.

without the presence of precipitation over the straw and capillary irrigation (T7) did not provide a satisfactory control of $E$. heterophylla in all assessments performed. A possible explanation for this is that because of the daily irrigation of this treatment having been carried out by capillary action, the product probably bonded to the straw. The daily irrigation in treatments without precipitation (T6) provided the leaching of aminocyclopyrachlor, controlling the E. heterophylla plants in the assessments at 28 and 35 DAA (Table 2).

For the number of $E$. heterophylla plants, it was found that only treatments without the application of herbicide (T1 and T2) have shown more infestation. Thus, it was noted that E. heterophylla showed excellent results in treatments with the application of aminocyclopyrachlor at a dose of $90 \mathrm{~g} \mathrm{ha}^{-1}$ (Table 2).

Thus, it is possible to infer that the application of aminocyclopyrachlor directly into the soil is effective for control of I. triloba and E. heterophylla. When this herbicide is applied on the straw, it is necessary that precipitation occur to move it from this layer to the soil surface and satisfactorily control these species. This occurs by the the physicochemical properties of this molecule. The high solubility $\left(4,200 \mathrm{mg} \mathrm{L}^{-1}\right)$ and its low octanol-water partition coefficient $\left(\mathrm{K}_{\mathrm{ow}}\right)$ of 2.48 (Finkelstein et al., 2008) provide low adsorption of this herbicide to the straw. According to
Christofoletti et al. (2009), hydrophilic or polar herbicides $\left(\mathrm{K}_{\mathrm{ow}}\right.$ values < 10), as is the case of aminocyclopyrachlor, have low affinity to lipid materials and, consequently, low adsorption to the straw, because of its high solubility.

\section{Indaziflam}

Table 3 shows the results of control and amount percentage of I. triloba plants after applying indaziflam. The results obtained in the first assessment (7 AAD) show that the higher control percentages of I. triloba occurred in the treatment in which the application was performed directly on the soil (T3) and also in that treatment where rainfall was simulated in order to carry the herbicide to the soil (T5).

In general, it was found that when rainfall was not simulated after application of the herbicide on the straw and maintenance irrigation was performed by capillarity (T7), there was development of the I. triloba plants similarly to the control without herbicide.

Table 4 shows the results of control and amount percentages of $E$. heterophylla plants after applying indaziflam. This herbicide proved to be a very effective product in the control of E. heterophylla in all assessment periods. In the assessment done at $7 \mathrm{DAA}$, satisfactory control of this weed has already been observed in the treatments with application directly into the soil (T3 and T8) 
Table 3 - Control percentage at 7, 14, 21 and 28 days after application (DAA) and number of I. triloba plants at 28 DAA of the treatments with indaziflam. Campo Mourão, PR, 2014

\begin{tabular}{|c|c|c|c|c|c|c|c|c|}
\hline \multirow{2}{*}{ Treatment } & \multirow{2}{*}{ Herbicide } & \multirow{2}{*}{$\begin{array}{l}\text { Sugarcane } \\
\text { straw }\end{array}$} & \multirow{2}{*}{$\begin{array}{c}\text { Simulated } \\
\text { rainfall } \\
(\mathrm{mm})\end{array}$} & \multicolumn{4}{|c|}{ Control (\%) } & \multirow{2}{*}{$\begin{array}{c}\begin{array}{c}\text { Number of } \\
\text { plants }\end{array} \\
28 \text { DAA } \\
\end{array}$} \\
\hline & & & & 7 DAA & 14 DAA & $21 \mathrm{DAA}$ & 28 DAA & \\
\hline 1 & Without & Without & Without & $0.0 \mathrm{c}$ & $0.0 \mathrm{~b}$ & $0.0 \mathrm{c}$ & $0.0 \mathrm{~b}$ & $4.5 \mathrm{a}$ \\
\hline 2 & Without & With & Without & $0.0 \mathrm{c}$ & $0.0 \mathrm{~b}$ & $0.0 \mathrm{c}$ & $0.0 \mathrm{~b}$ & $4.2 \mathrm{a}$ \\
\hline 3 & On the soil & Without & Without & $82.5 \mathrm{a}$ & $85.0 \mathrm{a}$ & $82.5 \mathrm{a}$ & $85.0 \mathrm{a}$ & $1.0 \mathrm{~b}$ \\
\hline 4 & On the straw & With & 20 & $25.0 \mathrm{~b}$ & $71.2 \mathrm{a}$ & $25.0 \mathrm{~b}$ & $71.2 \mathrm{a}$ & $1.5 \mathrm{~b}$ \\
\hline$* 5$ & On the straw & With & 20 & $80.0 \mathrm{a}$ & $83.0 \mathrm{a}$ & $80.0 \mathrm{a}$ & $83.0 \mathrm{a}$ & $2.0 \mathrm{~b}$ \\
\hline 6 & On the straw & With & Without & $71.2 \mathrm{a}$ & $80.0 \mathrm{a}$ & $71.2 \mathrm{a}$ & $80.0 \mathrm{a}$ & $3.7 \mathrm{a}$ \\
\hline$* 7$ & On the straw & With & Without & $0.0 \mathrm{c}$ & $0.0 \mathrm{~b}$ & $0.0 \mathrm{c}$ & $0.0 \mathrm{~b}$ & $3.5 \mathrm{a}$ \\
\hline 8 & Under the straw & With & Without & $77.5 \mathrm{a}$ & $86.2 \mathrm{a}$ & $77.5 \mathrm{a}$ & $86.2 \mathrm{a}$ & $0.7 \mathrm{~b}$ \\
\hline CV (\%) & & - & & 29.04 & 19.16 & 24.42 & 18.42 & 49.23 \\
\hline
\end{tabular}

Means followed by the same letter in each column do not differ by the Scott-Knott test $(\mathrm{p}<0.05) .{ }^{*}$ Treatments irrigated by capillarity.

Table 4 - Control percentage at 7, 14, 21 and 28 days after application (DAA) and number of E. heterophylla plants at 28 DAA of the treatments with indaziflam. Campo Mourão, PR, 2014

\begin{tabular}{|c|c|c|c|c|c|c|c|c|}
\hline \multirow{2}{*}{ Treatment } & \multirow{2}{*}{ Herbicide } & \multirow{2}{*}{$\begin{array}{l}\text { Sugarcane } \\
\text { straw }\end{array}$} & \multirow{2}{*}{$\begin{array}{l}\text { Simulated } \\
\text { rainfall } \\
(\mathrm{mm})\end{array}$} & \multicolumn{4}{|c|}{ Control (\%) } & \multirow{2}{*}{$\begin{array}{c}\text { Number o } \\
\text { plants }\end{array}$} \\
\hline & & & & 7 DAA & 14 DAA & $21 \mathrm{DAA}$ & $28 \mathrm{DAA}$ & \\
\hline 1 & Without & Without & Without & $0.0 \mathrm{~d}$ & $0.0 \mathrm{~d}$ & $0.0 \mathrm{~d}$ & $0.0 \mathrm{~d}$ & $5.5 \mathrm{a}$ \\
\hline 2 & Without & With & Without & $0.0 \mathrm{~d}$ & $0.0 \mathrm{~d}$ & $0.0 \mathrm{~d}$ & $0.0 \mathrm{~d}$ & $6.5 \mathrm{a}$ \\
\hline 3 & On the soil & Without & Without & $100.0 \mathrm{a}$ & $98.0 \mathrm{a}$ & $100.0 \mathrm{a}$ & $98.0 \mathrm{a}$ & $0.0 \mathrm{~b}$ \\
\hline 4 & On the straw & With & 20 & $81.2 \mathrm{~b}$ & $83.7 \mathrm{~b}$ & $81.2 \mathrm{~b}$ & $83.7 \mathrm{~b}$ & $3.0 \mathrm{~b}$ \\
\hline$* 5$ & On the straw & With & 20 & $98.5 \mathrm{a}$ & $85.0 \mathrm{~b}$ & $98.5 \mathrm{a}$ & $85.0 \mathrm{~b}$ & $2.0 \mathrm{~b}$ \\
\hline 6 & On the straw & With & Without & $23.7 \mathrm{c}$ & $45.0 \mathrm{c}$ & $23.7 \mathrm{c}$ & $45.0 \mathrm{c}$ & $5.2 \mathrm{a}$ \\
\hline$* 7$ & On the straw & With & Without & $0.0 \mathrm{~d}$ & $0.0 \mathrm{~d}$ & $0.0 \mathrm{~d}$ & $0.0 \mathrm{~d}$ & $5.2 \mathrm{a}$ \\
\hline 8 & Under the straw & With & Without & $78.7 \mathrm{~b}$ & $80.5 \mathrm{~b}$ & $78.7 \mathrm{~b}$ & $80.5 \mathrm{~b}$ & $2.0 \mathrm{~b}$ \\
\hline $\mathrm{CV}(\%)$ & & - & & 29.04 & 19.16 & 21.04 & 18.92 & 59.29 \\
\hline
\end{tabular}

Means followed by the same letter in each column do not differ by the Scott-Knott test $(\mathrm{p}<0.05)$ * Treatments irrigated by capillarity.

and in those with the presence of straw and rainfall simulation (T4 and $\mathrm{T} 5$ ). The same trend occurred in subsequent assessments, so that those were the most effective treatments to control $E$. heterophylla.

It can be seen that in the treatments with straw, rain simulation shortly after application is essential for indaziflam efficiency. This is evident when comparing the control of E. heterophylla in T6 and T7, where these treatments did not receive simulated rainfall after application of the herbicide and were the only ones which received the herbicide, but provided no satisfactory control of this species (Table 4). These results corroborate those found by Rossi et al. (2013) for herbicide metribuzin, who further observed higher transposition of the herbicide to the soil when precipitation simulation was done on the same day of herbicide application.

Due to the great importance of water in removing the product from the straw and transporting to the soil in both weeds analyzed, there was $0 \%$ of control in $\mathrm{T} 7$ because its irrigation was performed by capillary action, with no water contact with the straw and the product (Tables 3 and 4).

The best results in I. triloba and $E$. heterophylla regarding the number of plants (Tables 3 and 4) are those in which the 
treatments received application of indaziflam directly into the soil (T3 and T8); however, percentage and number of plants obtained were equally satisfactory in the treatments with rain simulation $(20 \mathrm{~mm})$ (T4 and $\mathrm{T} 5)$. Rain is responsible for the transport of the herbicide to the soil. Several studies have demonstrated that the first $20 \mathrm{~mm}$ are responsible for the initial loading of most of the herbicides, showing their high transport capacity (Prado et al., 2010; Rossi et al., 2013).

T7, whose irrigation was performed by capillary action and with no rain simulation, did not provide satisfactory results equivalent to those of controls without indaziflam (T1 and T2). The treatment that received the application of indaziflam with no rainfall simulation and maintenance irrigation on the layer of straw (T6) also provided greater a number of Ipomoea triloba and Euphorbia heterophylla plants. These results indicate that, for herbicide indaziflam to promote satisfactory weed control when applied on the straw, it is essential that precipitation occurs as soon as possible after the application to remove the herbicide from the straw and transport it to the soil, where the weed seeds are found. Cavenaghi et al. (2007), working with herbicide amicarbazone, have observed that the greater the time interval between the application of herbicide and the first rain, the lower the percolation of the straw herbicide to the soil, significantly interfering in weed control.

Indaziflam has low solubility in water (4.4 $\mathrm{mg} \mathrm{L}^{-1} \mathrm{pH} 4.0$ and $2.2 \mathrm{mg} \mathrm{L}^{-1} \mathrm{pH} \mathrm{7.0)} \mathrm{and}$ low $\mathrm{K}_{\text {ow }}$ (2.80) (Bayer, 2010). According to Christofoletti et al. (2009), herbicides with lower retention on the straw are the ones with higher solubility and lower $\mathrm{K}_{\text {ow }}$; in the case of indaziflam, it was found that, even with low solubility, it was transported from the straw to the soil surface by $20 \mathrm{~mm}$ simulated rainfall after application. Probably, if that precipitation took longer to occur, the amount of herbicide to be detached from the straw would be less and weed control would be jeopardized.

Comparing the two experiments, it is possible to conclude that herbicides aminocyclopyrachlor and indaziflam applied directly to the soil were effective in controlling I. triloba and E. heterophylla. The precipitation simulation (at least $20 \mathrm{~mm}$ ) or daily irrigation, both on the straw, are essential to promote the removal of such herbicides from the straw and provide satisfactory control of these species.

\section{LITERATURE CITED}

BAYER ENVIRONMENTAL SCIENCE. Specticle herbicide technical bulletin; 2010. $16 \mathrm{p}$.

CARBONARI, C. A. Eficácia do herbicida amicarbazone em aplicação conjunta com a colheita de cana-de-açúcar no controle das principais plantas daninhas da cultura. 2007. 127 f. Dissertação (Mestrado em Agronomia) Universidade Estadual Paulista “Julio de Mesquita Filho”, Botucatu, 2007.

CARBONARI, C. A. et al. Eficácia do herbicida diclosulam em associação com a palha de sorgo no controle de Ipomoea grandifolia e Sida rhombifolia. Planta Daninha, v. 26, n. 3, p. 657-664, 2008.

CAVENAGHI, A. L. et al. Dinâmica do herbicida amicarbazone aplicado sobre a palha de cana-de-açúcar. Planta Daninha, v. 25, n. 4, p. 831-837, 2007.

CHRISTOFFOLETI, P. J. et al. Comportamento dos herbicidas aplicados ao solo na cultura da cana-deaçúcar. Piracicaba: 2009. 72 p.

CORREIA, N. M.; REZENDE, P. M. D. Manejo integrado de plantas daninhas na cultura da soja. 2002. Disponível em: <http://www.editora.ufla.br/upload/boletim/tecnico/ boletim-tecnico-51.pdf> Acesso em: 20 ago. 2013.

EMPRESA BRASILEIRA DE PESQUISA AGROPECUÁRIA - EMBRAPA. Centro Nacional de Pesquisas de Solos. Sistema brasileiro de classificação de solos. 2.ed. Rio de Janeiro: Embrapa Solos, 2013. 305 p.

FERREIRA, E. A. et al. Manejo de plantas daninhas em canacrua. Planta Daninha, v. 28, n. 4, p. 915-925, 2010.

FINKELSTEIN, B. L. et al. Discovery of aminocyclopyrachlor (proposed common name) (DPXMAT28): a new broad spectrum auxinic herbicide. In: ACS National Meeting in Philadelphia, PA, 236 ${ }^{\mathrm{TH}}$., 2008, Washington. Proceedings... Washington: American Chemical Society, 2008.

GUERRA, N. et al. Aminocyclopyrachlor e indaziflam: seletividade, controle e comportamento no ambiente. R. Bras. Herb., v. 12, n. 3, p. 285-295, 2013. 
LAMOREAUX, R. J.; JAIN, R.; HESS, F. D. Efficacy of dimethenamid, metolachlor and encapsulated alachlor in soil covered with crop residue. Bringhton Crop Protec. Conf. Weeds, v. 3, p. 1015-1020, 1993.

LOCKE, M. A.; BRYSON, C. T. Herbicide-soil interaction in reduced tillage and plant residue management systems.

Weed Sci., v. 45, n. 2, p. 307-320, 1997.

MACIEL, C. D. G.; VELINI, E. D. Simulação do caminhamento da água da chuva e herbicidas em palhadas utilizadas em sistema de plantio direto. Planta Daninha, v. 23, n. 3, p. 471-481, 2005.

MARTINS, D. et al. Emergência em campo de dicotiledôneas infestantes em solo com palha de cana-de-açúcar.

Planta Daninha, v. 17, n. 1, p. 151-161, 1999.

MONQUERO, P. A. et al. Eficácia de herbicidas em diferentes quantidades de palha de cana-de-açúcar no controle de Ipomoea grandifolia. Bragantia, v. 68, n. 2, p. 367-372, 2009.
PRADO, A. B. C. A. et al. Dinâmica de herbicidas aplicados em pré-emergência sobre palha de cana-de-açúcar em diferentes regimes hídricos. R. Bras. Herb., v. 12, n. 2, p. 179-187, 2010.

ROSSI, C. V. S. et al. Dinâmica do herbicida metribuzin aplicado sobre palha de cana-de-açúcar (Saccharum officinarum). Planta Daninha, v. 31, n. 1, p. 223-230, 2013.

SOCIEDADE BRASILEIRA DA CIÊNCIA DAS PLANTAS DANINHAS - SBCPD. Procedimento para instalação, avaliação e análise de experimentos com herbicidas. Londrina: 1995. 42 p.

UNIÃO DOS PRODUTORES DE BIOENERGIA - UDOP. Ministério da Agricultura, Pecuária e Abastecimento. 2015. Disponível em: http://www.udop.com.br/download/ estatistica/acucar_producao/20fev15_producao_acucar.pdf $>$. Acesso em: 13 mar. 2015. 